\title{
PHAGOCYTOSIS ACTIVITY OF BINAHONG (Anredera cordifolia (Tenore.) Steenis) FROM SECANG, MAGELANG, CENTRAL JAVA, INDONESIA
}

\author{
Dika Sotya Sakti, Perdana Priya Haresmita, Nunung Yuniarti*), Subagus Wahyuono
}

Faculty of Pharmacy, Universitas Gadjah Mada, Bulaksumur, Yogyakarta, Indonesia

Received January 14, 2019; Accepted March 18, 2019

\begin{abstract}
The use of medicinal plants is increasing due to the search for alternative resources to treat diseases such as hypertensions and infection. Along with the development in science, preventive action should take place to prevent our body from suffering from these diseases. This can be done by increasing the human immune status with immunomodulatory agents. Binahong empirically have benefits for wound healing. The purpose of this research was to investigate the immunomodulatory effect of ethanolic extract of binahong leaves. The non-specific modulatory effects of the ethanolic extracts of binahong leaves on the immune systems were measured based on phagocytosis index and phagocytosis capacity. Tests were conducted on strain Balb/C male mice at the age of 6-8 weeks. Mice were administered orally with the extract of binahong leaves (doses of $25,50,75 \mathrm{mg} / \mathrm{kgBW}$ ) for 14 days. The test results with the index parameters and macrophages phagocytosis capacity at doses of 50 and $75 \mathrm{mg} / \mathrm{kgBW}$ did not significantly increased when compared with the controls. From these results, we concluded that the ethanolic extract of binahong leaves with a dose of 25,50 and $75 \mathrm{mg} / \mathrm{kgBW}$ cannot significantly the activity of macrophages by phagocytosis index parameters and phagocytosis capacity significantly.
\end{abstract}

Keywords: Anredera cordifolia; immunomodulatory agent; macrophage; phagocytosis capacity; phagocytosis index

\section{INTRODUCTION}

Medicinal plants have been used as an alternative to synthetic drugs, for a long time. Medicinal plants are potential sources of drugs and are widely used to gain health benefit empirically (Rodríguez et al., 2018). Medicinal plants are used because they are easier to obtain, cheaper than synthetic drugs and have less side effect (Wardhani and Sulistyani, 2013). Various diseases such as hypertension, diabetes mellitus, headache, inflammation and modulation of the immune system have been widely treated with medicinal plants (Leliqia et al., 2017; Putri et al., 2017).

Binahong (Anredera cordifolia (Ten.) Steenis) is one of the species from the family of Basellaceae, which has fleshy leaves and thick aerial tubers. It is widely used as a medicinal plant in Indonesia. Binahong leaves are used for treatment of wounds, refreshing the body, headache and lowering blood pressure. Ether fraction of binahong leaves extract exhibited antioxidant activity measured by DPPH (1,1-diphehyl-2-picrylhydrazyl) (Ardianti and Guntarti, 2014). Binahong leaves extract accelerated wound healing infected by Staphylococcus aureus in mice. Binahong leaves extract also inhibited the growth of Staphylococcus aureus and as a result, the healing process the wounds is faster than wound healing without binahong leaves extract (Umar et al., 2012). Topical application of binahong leaves extract makes wound healing process faster, IL-6 level higher and increases vascular endothelial growth factor (VEGF) production in burns 
infected by Pseudomonas aeruginosa (Sukrama et al., 2017).

We therefore designed this study to determine the immunomodulatory effects of binahong leaves extract by measuring phagocytosis activity and phagocytosis index. The antimicrobial-antioxidant activity was correlated with immunomodulatory effects (Umar et al., 2012; Yuniarti and Lukiswanto, 2017). Phagocytosis ratio indicates the percentage of active macrophage to 100 macrophages, and phagocytosis index indicates the number of latex able to be consumed by active macrophages. These number are compared to the controls.

\section{METHODS}

\section{Research Materials}

CMC-Na, Distilled water, alcohol 70\%, ethanol $96 \%$ (General Labora), methanol, Giemsa $20 \%$, latex beads (Sigma ${ }^{\mathrm{TM}}$ ), RPMI medium 1640 (Gibco $\left.^{\mathrm{TM}}\right)$, FBS $\left(\mathrm{Sigma}^{\mathrm{TM}}\right)$, Fungizone $\left(\mathrm{Gibco}^{\mathrm{TM}}\right)$, pen-strep $\left(\mathrm{Gibco}^{\mathrm{TM}}\right)$, PBS $\left(\right.$ Sigma $\left.^{\mathrm{TM}}\right)$, hepatitis $\mathrm{B}$ vaccine $\left(\operatorname{Euvax}^{\mathrm{TM}}\right)$.

\section{Preparation of sample}

Binahong plant leaves were obtained from the District Secang, Magelang, Central Java. The identify was authenticated by the Department of Pharmaceutical Biology, Faculty of Pharmacy, Universitas Gadjah Mada in certificate number UGM/FA/2413/M/03/02. Based on the results, the plants studied is binahong (Anredera cordifolia (Tenore) Steenis).

\section{Preparation of animal test}

Male mice, strain Balb/c aged 6-7 weeks weighing 25-35 g were obtained from the Animal Cage Test Faculty of Pharmacy, Universitas Gadjah Mada. The protocol of the study was approved by the Ethics Commission for Preclinical Trials of Integrated Research and Testing Laboratory (LPPT), Universitas Gadjah Mada with certificate number 00123/04/LPPT/X/2017.

\section{Extraction of binahong leaves}

Binahong leaves were obtained from Secang, Magelang Regency, Central Java Province, Indonesia. Powdered leaves material of Anredera cordifolia was macerated with ethanol $96 \%(2 x)$ for 24 hours each, filtered and the filtrates obtained were combined and evaporated in vacuum to give thick liquid material of ethanol extract. The ethanol extract with the dose of 25,50 and $75 \mathrm{mg} / \mathrm{kgBW}$ were given orally to assess its immunomodulatory effects by measuring macrophage activity using phagocytosis index and phagocytosis capacity and compared with normal and CMC-Na groups.

\section{Immunomodulatory assay (macrophage activity assay) \\ Preparation of macrophage cells}

Macrophage cells were isolated from BALB/c mice (6-8 weeks old). Mice were euthanized with neck dislocation and $10 \mathrm{~mL}$ of cold RPMI medium were then injected inside the stomach. After 3-5 minutes, the RPMI was withdrawn from the stomach using syringe and put into a conical flask, centrifuged at $1,500 \mathrm{rpm}\left(4^{\circ} \mathrm{C}\right.$, for 10 minutes $)$. The supernatant was removed and the residue resuspended with RPMI $(80 \%$ FBS $)$. The numbers of cells was calculated with hemocytometer, diluted with RPMI (80\% FBS) till $2.5 \times 106 / \mathrm{mL}$ cells density was obtained. The cells suspension that had been cultured on 24 wells $(200 \mu \mathrm{L} /$ well, $5 \times 105$ cells/well) plate for 24 hours was put in round coverslips, incubated in a $\mathrm{CO}_{2}(5 \%)$ incubator, at $37^{\circ} \mathrm{C}$ for 30 minutes and then complete medium, containing $10 \% \mathrm{FBS}$, fungizone $0.5 \%$ and penicillin streptomycin $2 \%(1.0 \mathrm{~mL})$ was added to each well and then incubated for another 2 hours. The cells were washed twice with RPMI, and then complete medium (1.0 $\mathrm{mL}$ ) was added to each well and incubated for the next 24 hours (Hartini et al., 2013).

\section{Macrophages activity measurement}

Macrophages activity measurement was done involving latex $(2 \mu \mathrm{m}$ in diameter $)$ as substrates (suspended in PBS, at $2.5 \mathrm{x}$ $107 / \mathrm{mL})$. The cells suspension $(200 \mu \mathrm{L})$ was 
added into each well containing peritoneum macrophages, then incubated for another 60 minutes in a $\mathrm{CO}_{2}$ incubator. The cells suspension was washed 3 times with PBS in order to remove particles. The cells suspension was dried at room temperature and then fixed with methanol. Coverslips were dyed with Giemsa $20 \%$ for 20 minutes, washed with aquadest, lifted up from the wells and re-dried at room temperature. The macrophages activity was calculated as the number $(\%)$ of consumed latex (substrates), visualized by light microscope (magnified 400x) as seen as Figure 1. Phagocytosis ratio was indicated by the percentage of active macrophage in 100 macrophages, and phagocytosis index was indicated by the number of latex able to be consumed by active macrophages (Hartini et al., 2014). These data were compared to the controls.

\section{RESULTS AND DISCUSSION}

The parameters of the observed activity of macrophages were phagocytosis capacity of macrophages and macrophage phagocytosis index. Macrophage phagocytosis capacity was obtained by calculating the percentage of the number of active macrophages phagocyted latex beads per 100 macrophages observed, whereas macrophage phagocytosis index was obtained by counting the number of latex beads phagocyted per 100 macrophages (Jensch-Junior et al., 2006). These parameters would be able to show immunostimulatory effects of ethanolic extract of binahong leaves.

Macrophages were isolated from the peritoneal cavity of mice because the number of macrophages in the peritoneal cavity is larger than the other organs and easy to obtain from the peritoneal fluid. The medium used was RPMI because this medium can attract macrophages in the peritoneal cavity and provide nutrition such as vitamins, amino acids, and essential materials required for macrophage cell culture processes. Liquids that have been isolated from the peritoneal cavity contains not only macrophage cells but also granulocytes and lymphocytes. Peritoneal fluid that was place into a conical flasks was centrifuged to separate macrophage cells from other cells such as lymphocytes and granulocytes (Hay and Westwood, 2002).

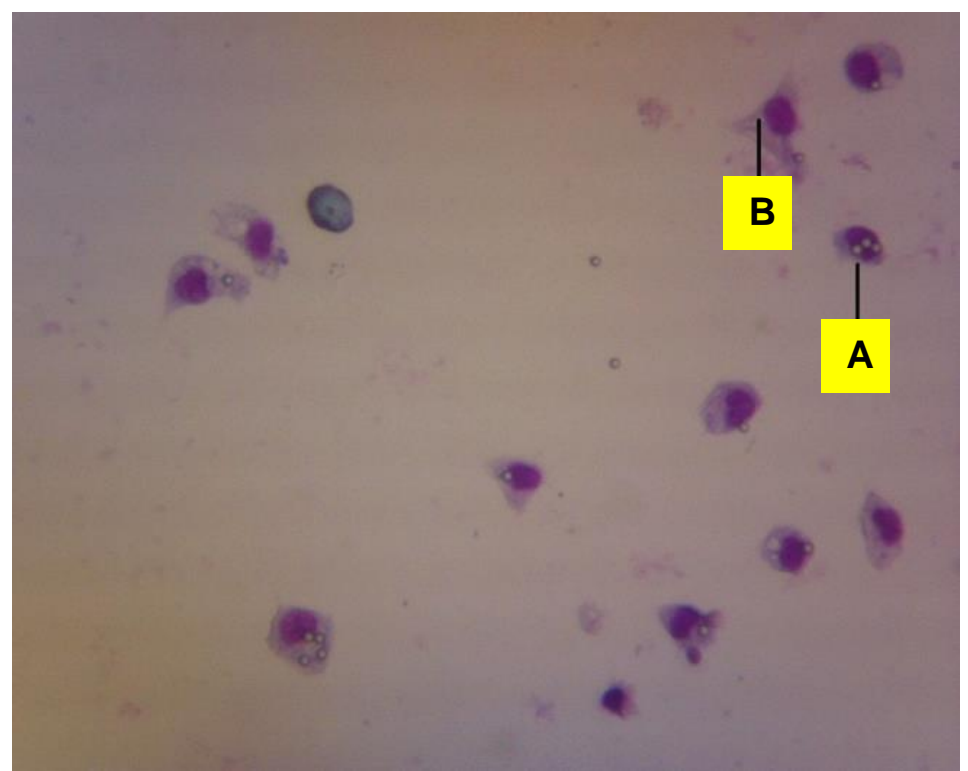

Figure 1. Macrophage observation under microscope magnification 400x. A: active macrophage; B: inactive macrophage. 
A

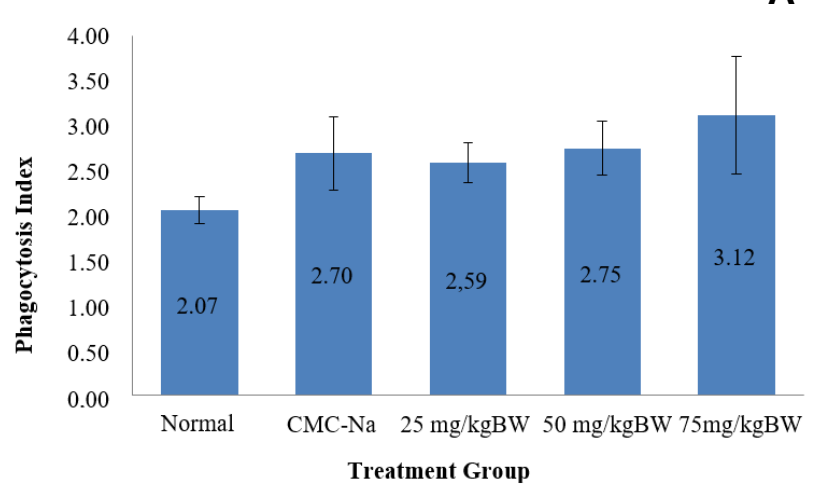

B

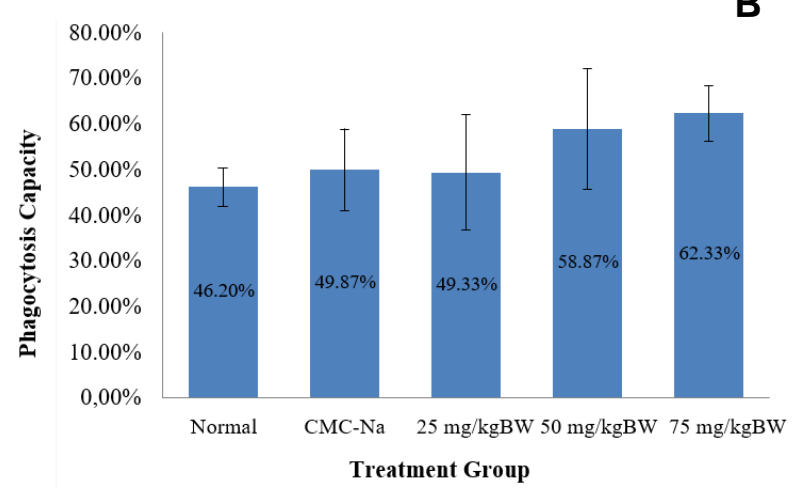

Figure 2. Results of statistical analysis of phagocytosis index (A) and phagocytosis capacity (B).

Table I. Phagocytosis Capacity and Phagocytosis Index of Binahong Leaves Ethanolic Extracts

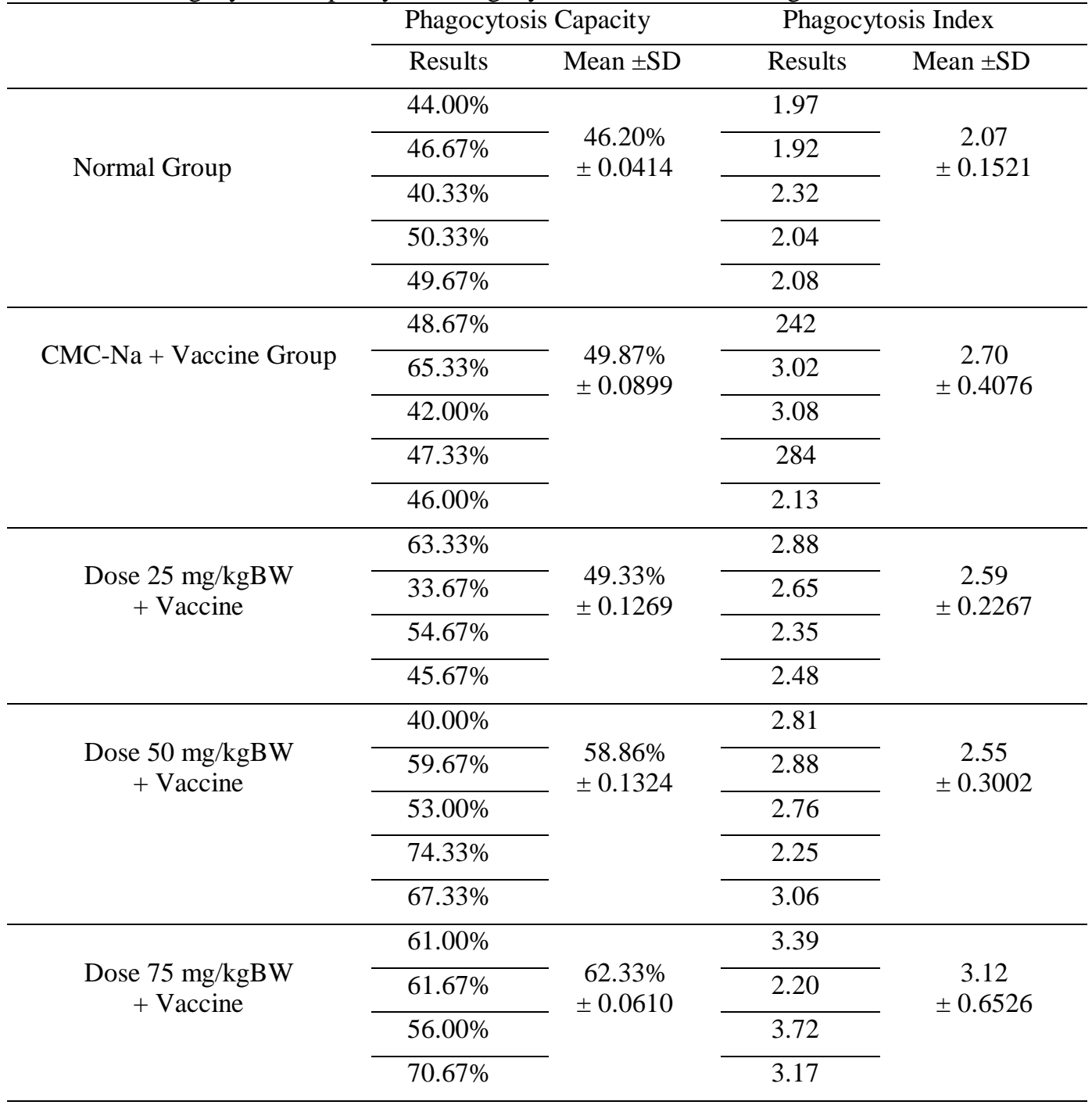


Hepatitis B vaccine was administered intraperitoneally on day 5 and 12 as an immune booster. The first vaccination was done to activate the non-specific and specific immune system and the second vaccination was done to increase the expression of the immune system (as a booster) so it is easier to analyze. Surgery was performed on the 15 th day because the immune system will be activated optimally up to 3 days after induction of the vaccine and gradually decline thereafter (Abbas et al., 2014).

Quantification of macrophages was performed using latex beads with a size of 3 $\mu \mathrm{m}$ which were resuspended in the serum of test animals. The size of the latex beads that resemble the size of bacteria could trigger macrophage phagocytosis by being perceived as foreign particles. The addition of serum of the test animals into the latex suspension would help the macrophage phagocytosis process as serum would facilitate the introduction of the antigen by macrophages (Harvath and Terle, 1999).

Based on our results which was presented in Table I, after examining macrophage phagocytic capacity and macrophage phagocytosis index, the ethanolic extract of binahong leaves at dose of 25,50 and 75 $\mathrm{mg} / \mathrm{kgBW}$ did not significantly enhance the ability of macrophage through an increase of both parameters compared with the control group $0.5 \%$ CMC-Na. A significant difference was found only in the phagocytosis index data for the dose group $75 \mathrm{mg} / \mathrm{kgBW}$ when compared with the normal group, as seen as in Figure 2.

According to previous research, $70 \%$ ethanolic extract of binahong leaves dose of $50 \mathrm{mg} / \mathrm{kgBW}$ could raise the profile of leukocytes as an increase in total leukocytes, neutrophils and total monocytes in guinea pigs (Wijayanti et al., 2018). In addition, the ethanolic extract of binahong leaves at concentrations of $50 \%$ and $100 \%$ could increase the phagocytic monocytes with in vitro method (Wahyukundari and Praharani, 2016). Monocytes are produced by the bone marrow which would circulate in the blood before it becomes differentiated in the tissue to macrophages. Other studies found that binahong leaves extract can also increase the production of interleukin- 6 in the blood plasma of mice during the healing of burns. Interleukin- 6 is a cytokine produced by T-cells and macrophages to stimulate the immune response during an infection or during the healing process (Sukrama et al., 2017). From the previous research of Sukrama et al., (2017) and Wijayanti et al., (2018), ethanolic extract of binahong leaves has the effect to increase the response of the immune system, but in the present study, the increasing phagocytosis capacity and phagocytosis index were not significant when compared to the control group.

Research by Wijayanti et al., (2018) was using a guinea pig test animals while this study used Balb/c strain mice. Previous research was conducted to see the effect of binahong leaves extract on blood leukocytes profile and the average number of descendants of the test animals. The increase in the number of monocytes as one of the parameters of blood leukocytes profile in these studies was not always followed by an increase in activity of macrophages in the tissue. Monocytes from the blood can differentiate into multiple cell types of the immune system and in such a network of dendritic cells, osteoclasts and macrophages depends on the existing stimulus inside the body. Monocyte activity in the network tends to be more specific and different in each tissue. The difference is caused by different stimuli derived from the macrophage microenvironment (Hulin et al., 1995).

Research conducted by Wahyukundari et al. (2016) was performed in vitro by taking blood monocytes. Experiments in vitro have less variables that cannot be controlled as compared to experiments in vivo. In vivo experiments involve factors including pharmacokinetics (absorption, distribution, metabolism and excretion) and the first-past effect that could affect the availability of the extract in the body. In addition, the physiological state of the test animals such as hormones could also influence the effect of the test sample. Absorption through the oral drug 
has a lower bioavailability compared with administration by injection and the drug can be metabolized by gastrointestinal fluids or often called first-past experience effect (Atanasov et al., 2015).

Another factor that could affect the results when compared with previous studies was the source of the sample. Wahyukundari and Praharani (2016) collected the binahong leaves from Jember, East Java whereas in this study the binahong leaves were collected from Secang, district of Magelang, Central Java. Different areas could cause differences in the content of secondary metabolites in plants because each area has different soil nutrients. Differences in soil nutrients would affect the availability of nutrients and plant precursor to form secondary metabolites (Salim et al., 2017).

\section{CONCLUSION}

Ethanolic extract of binahong leaves at dose of 25,50 and $75 \mathrm{mg} / \mathrm{kgBW}$ cannot significantly increase the activity of macrophages by phagocytosis index parameters and phagocytic capacity.

\section{REFERENCES}

Abbas, A.K., Lichtman, A.H., and Pillai, S., 2014. Cellular and Molecular Immunology, Eighth edition, Elsevier Saunders.

Ardianti, A. and Guntarti, A., 2014. Uji Aktivitas Antioksidan Fraksi Eter Hasil Hidrolisis Infusa Daun Binahong (Anredera cordifolia (Ten.) Steenis) dengan Metode DPPH (1,1-diphenil-2picrylhydrazyl). Pharmaciana, (4), 18.

Atanasov, A.G., Waltenberger, B., PferschyWenzig, E., Linder, T., Wawrosch, C., Uhrin, P., Temml, V., Wang, L., Schwaiger, S., Heiss, E.H., Rollinger, J.M., Schuster, D., Breuss, J.M., Bochkov, V.N., Mihovilovic, M.D., Kopp, B., Bauer, R., Dirsch, V.M., and Stuppner, H., 2015. Discovery and Resupply of Pharmacologically Active Plant-Derived Natural Products: A review. Biotechnological Advance,
(33), 1582-1614.

Hartini, Y.S., Wahyuono, S., Widyarini, S., and Yuswanto, A., 2013. Phagocytic Macrophage Activity of Fractions from Methanolic Leaf Extract of Red Betel (Piper crocatum Ruiz \& Pav.) In Vitro. Jurnal Ilmu Kefarmasian Indonesia, (11), 108-115.

Hartini, Y.S., Wahyuono, S., Widyarini, S., and Yuswanto, A., 2014. In vivo Immunomodulatory Effect and Histopathological Features of Mouse Liver and Kidney Treated With Neolignans Isolated from Red Betel (Piper crocatum Ruiz \& Pav) Leaf. Tropical Journal of Pharmaceutical Research. (13), 1609-1614.

Harvath, L. and Terle, D.A., 1999. Assay for Phagocytosis, In: Javois, L.C., Immunocytochemical Methods and Protocols. New York: Humana Press, 281-290.

Hay, F.C. dan Westwood, O.M.R., 2002. Practical Immunology, Fourth edition, Blackwell Science, United Kingdom.

Hulin, I., Jakubovsky, J., and Viera, S., 1995. Inflammation and Fever, in: Hulin, I., Jakubovsky, J., and Viera, S., Pathophysiology Principles of Diseases. Bratislava: Comenius University, 65-72.

Jensch-Junior, B.E., Pressinotti, L.N., Borges, J.C.S., and da Silva, J.R.M.C., 2006. Characterization of macrophage phagocytosis of the tropical fish Prochilodus scrofa (Steindachner, 1881). Aquaculture, (251), 509-515.

Leliqia, N.P.E., Sukandar, E.Y., and Fidrianny, I., 2017. Overview of Efficacy, Safety and Phytochemical Study of Anredera cordifolia (Ten.) Steenis. Pharmacology Online, (1), 124-131.

Putri, D.U., Rintiswati, N., Soesatyo, M.H., and Haryana, S.M., 2017. Immune Modulation Properties of Herbal Plant Leaves: Phyllanthus niruri Aqueous Extract on Immune Cells of Tuberculosis Patient - in vitro Study. Natural Product Research, (32), 463- 
467.

Rodríguez, E.T., Frias, M. de la C., Galardis, M.B., and Leon, J.A.M., 2018. In Vitro Antibacterial Activity of Dried Extract from Anredera vesicaria Rhizomes. Journal Of Advance in Plants and Agricultural Research, (3), 237-239.

Salim, M., Yahya, Y., Sitorus, H., Ni'mah, T., and Marini, M., 2017. Hubungan Kandungan Hara Tanah dengan Produksi Senyawa Metabolit Sekunder pada Tanaman Duku (Lansium domesticum Corr var Duku) dan Potensinya sebagai Larvasida. Jurnal Vektor Penyakit, (10), 11-18.

Sukrama, D.M., Wihandani, D.M., and Manuaba, A.P., 2017. Topical Binahong (Anredera cordifolia) Leaf Extract Increases Interleukin-6 and VEGF (Vascular Endothelial Growth Factor) during Burn Wound Healing in Wistar Rats Infected with Pseudomonas aeruginosa. Biology and Medicine, (9), 1-6.

Umar, A., Krihariyani, D., and Mutiarawati, D.T., 2012. Pengaruh Pemberian
Ekstrak Daun Binahong (Anredera cordifolia (Ten.) Steenis) terhadap Kesembuhan Luka Infeksi Staphylococcus aureus pada Mencit. Analis Kesehatan Sains, 1 (2), 1-8.

Wahyukundari, M. and Praharani, D., 2016. Pengaruh Ekstrak Daun Binahong (Anredera cordifolia (Tenore) Steen.) terhadap Aktivitas Fagositosis Monosit. In: Proceeding Books Forkinas VI FKG Unej, 416-425.

Wijayanti, D., Setiatin, E.T., and Kurnianto, E., 2018. Leukocyte Profile and Offspring Production of Guinea Pig (Cavia cobaya) Given Anredera cordifolia Leaf Extract. Journal of the Indonesian Tropical Animal Agriculture, (43), 18-25.

Yuniarti, W.M. and Lukiswanto, B.S., 2017. Effects of Herbal Ointment Containing The Leaf Extracts of Madeira Vine (Anredera cordifolia (Ten.) Steenis) for Burn Wound Healing Process on Albino Rats. Veterinary World, (10), 808-813. 